\title{
Utilization of Stone Waste in the Development of Value Added Products: A State of the Art Review
}

\author{
Rajni Lakhani*, Rajesh Kumar and Priyanka Tomar \\ CSIR - Central Building Research Institute, Roorkee 247667, India
}

Received 15 January 2014; Accepted 16 July 2014

\begin{abstract}
The utilisation of stone waste, in the form of mineral admixture as a pozzolanic and non-pozzolanic material for mortar and concrete has received considerable attention in recent years. This interest is part of the widely spread attention directed towards the utilisation of wastes and industrial by-products in order to minimise Portland cement (PC) and sand consumption, the utilisationof which being environmentally damaging. Another reason is that mortar and concrete, which contain pozzolanic as well as non-pozzolanic materials, exhibit considerable enhancement in durability properties. This paper reviews work carried out on the use of stone waste as a partial non-pozzolanic replacement for sand in mortar and concrete and in the containment of hazardous wastes. The literature demonstrates that different stone wastes is an effective inert filler which causes great improvement in the pore structure and hence the resistance of the concrete to the action of harmful solutions.
\end{abstract}

Keywords: Stone waste;Stone cutting industry; Slurry disposal; Environmental management; Mechanical property

\section{Introduction}

Stone, one of the most common building material of ancient times, is an ubiquitous material. A sustainable growth in the consumption of stone is observed all over the world in the recent years. Various types of stone such as-granite, marble, limestone, slate etc. are used in construction purposes. The country wise production of stones is show in Fig.1 [1].

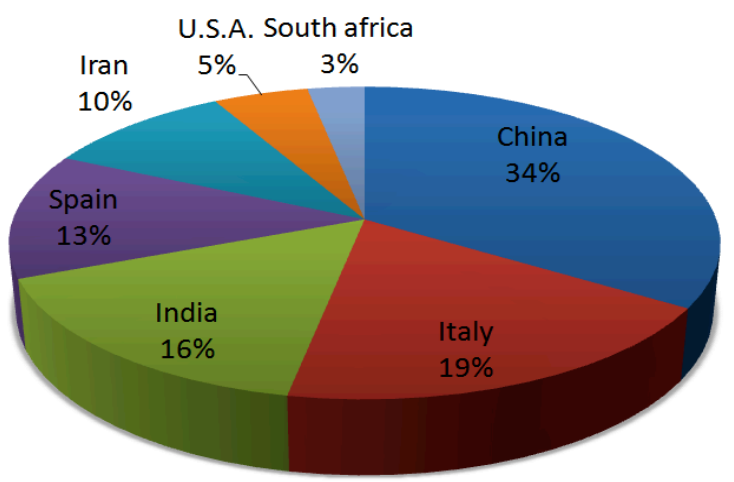

Fig. 1. Country v/s stone production (\%).

There is continuous increment in the demand of various types of stone which leads to enormous increase in the business of stone sector industry. Today, different operations on stones, like-quarrying, sawing, cutting etc. are being processed by modern technologies which are improving the rate of production of stones as well as stone waste continuously.

The stone waste is now-a-days a serious environment problem which is threat to modern civilization. As it is a non-biodegradable material, therefore poses numerous hazards. If this stone waste is dumped on land then, it can reduce the rate of rain water percolating and deteriorate the soil fertility. Stone waste dumped in rivers, streams and seas contaminates the water and marine [2]. Although land-filling can be an alternative to reuse stone waste but apart from this, it can also be used to make various cement composites, as one of the best solution for disposing of stone waste, due to its economical and ecological advantages (2-6).

An immense work has already been done on the use of stone waste in the production of Self-compacting concrete (SCC), Bricks, Mortar, Tiles, Cement concrete as aggregate and filler (7-12). The aim of the application of cutting and polishing stone waste in cementations system is to improve the characteristics of the fresh and hardened material. Stone waste has a filler effect by filling up the voids between the sand grains. With the proper grading, the higher packing density results in improvement of strength (Compressive strength, Tensile strength, Flexural strength), Durability issues, Abrasion resistance with decrement of Coefficient of permeability and Chloride ion penetration by formation of dense microstructure (13-20).

This paper reviews the engineering properties of stone waste, fresh and hardened properties and durability performance of cement mortar and concrete containing stone waste in the production of different construction materials. 


\section{Generation of stone waste}

In general there are two types of wastenamed as quarry/cutting/sawing from in-situ stone site and polishing waste from construction sites. During the processing of stone, the raw stone block is cut as demanded either into tiles or slabs of various thickness (usually 2 or $4 \mathrm{~cm}$ ), using diamond blades. Water is showered on blades while stone blocks are cut into sheets of varying thickness, to cool the blades and absorb the dust produced during the cutting operation. Theamount of wastewaterfrom this operation is very large. It is not recycled as the water is so highly alkaline that, if re-used, it can dim the slabs to be polished. In large factories, where the blocks are cut into slabs, the cooling water is stored in pits until the suspended particles settle (sedimentation tanks), then the slurry is collected in trucks and disposed off on the ground and left to dry. This water carries large amounts of stone powder. The polishing operation is fully automated with the use of powdered abrasives that keep on scrubbing the surface of the stone until it becomes smooth and shiny. Water showers are essential to prevent overheating of the blades. Generation and type ofstone waste is given below in Figs. 2 and 3:

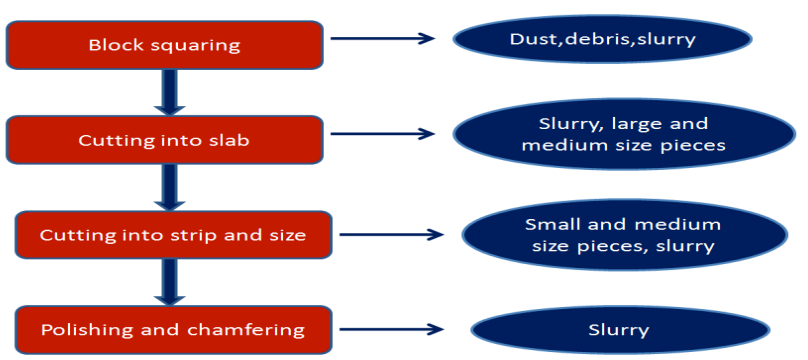

Fig 2. Generation of Stone Waste

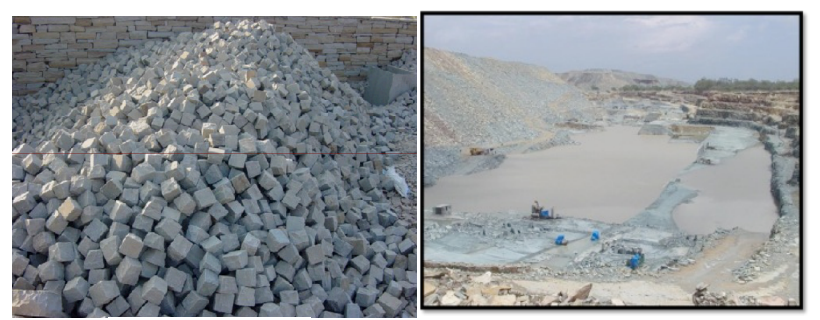

Fig. 3. Stone cutting waste.

\section{Problems by dumped stone waste}

In general, all the mines affect their surrounding environment to a little or more extent, but open cast mining i.e. in case of marble, granite, lime stone, sandstone and other type of building stone quarries leads to complex nature of environmental problems such as:

(1) Choking of drains in rainy season

(2) Dust nuisance

(3) Fine particles of slurry (with size less than 363 micron) become air borne and cause air pollution

(4) Slurry affects productivity of land due to decreased porosity, water absorption and percolation

(5) Slurry dumped areas cannot support vegetation and remain degraded

(6) Due to long-term deposition of slurry on land, the finer particles block the flow regime of aquifers. Thus, seriously affecting underground water availability

So these waste material needs to be utilized meaningfully in an economic way.

\section{Properties of stone waste}

Different stone waste like granite, marble, limestone, sandstone etc.have different properties. However, a particular stone waste may have different physical and chemical properties depending on the method of generation of waste. It has been found that in cutting waste, calcium oxide $(\mathrm{CaO})$ and in polishing waste, silicon-di-oxide $\left(\mathrm{SiO}_{2}\right)$ is the main constituent. The properties of some types of stone waste used as an aggregate in concrete are presented in Table 1 and 2. Table 3 indicates amount of substitution by stone waste in different proportions.

Table 1. Physical and mechanical properties of powder and slurry stone waste.

\begin{tabular}{|c|c|c|c|c|c|c|c|}
\hline \multirow[t]{2}{*}{ S.No. } & \multirow{2}{*}{$\begin{array}{l}\text { Types of stone waste } \\
\text { (Powder/Slurry) }\end{array}$} & \multicolumn{6}{|c|}{ Property } \\
\hline & & Specific gravity & $\begin{array}{l}\text { Bulk } \\
\text { density, } \\
\left(\mathrm{kg} / \mathrm{m}^{3}\right)\end{array}$ & $\begin{array}{l}\text { Water } \\
\text { absorption } \\
(\%)\end{array}$ & $\begin{array}{l}\text { Max. } \\
\text { particle } \\
\text { size }(\mathrm{mm})\end{array}$ & $\begin{array}{l}\text { Fineness } \\
\text { modulus(FM)/ } \\
\text { Blaine fineness } \\
\left(\mathrm{cm}^{2} / \mathrm{g}\right)^{*}\end{array}$ & Color \\
\hline 1 & Marble stone waste & $2.12-2.67$ & $\begin{array}{c}1300-1500 \\
\text { (SL) }\end{array}$ & $22-24(\mathrm{SL})$ & $\begin{array}{l}0.062 \\
\text { (Dry) }\end{array}$ & $5100-5250 *$ & $\begin{array}{c}\text { White/ } \\
\text { Dirty white }\end{array}$ \\
\hline 2 & Lime stone waste & $2.58-2.65$ & $1568-1743$ & $2-4$ & 0.2 (Dry) & $3900-4123^{*}$ & $\begin{array}{c}\text { White/ } \\
\text { Dirty white }\end{array}$ \\
\hline 3 & Granite stone waste & $2-2.84$ & $\begin{array}{c}1210-1465 \\
\text { (Dry) }\end{array}$ & 26-28 (SL) & $\begin{array}{l}0.065 \\
\text { (Dry) }\end{array}$ & $0.90-2.00(\mathrm{FM})$ & $\begin{array}{c}\text { Pink to } \\
\text { gray }\end{array}$ \\
\hline
\end{tabular}


Table 2: Chemical properties of different stone waste.

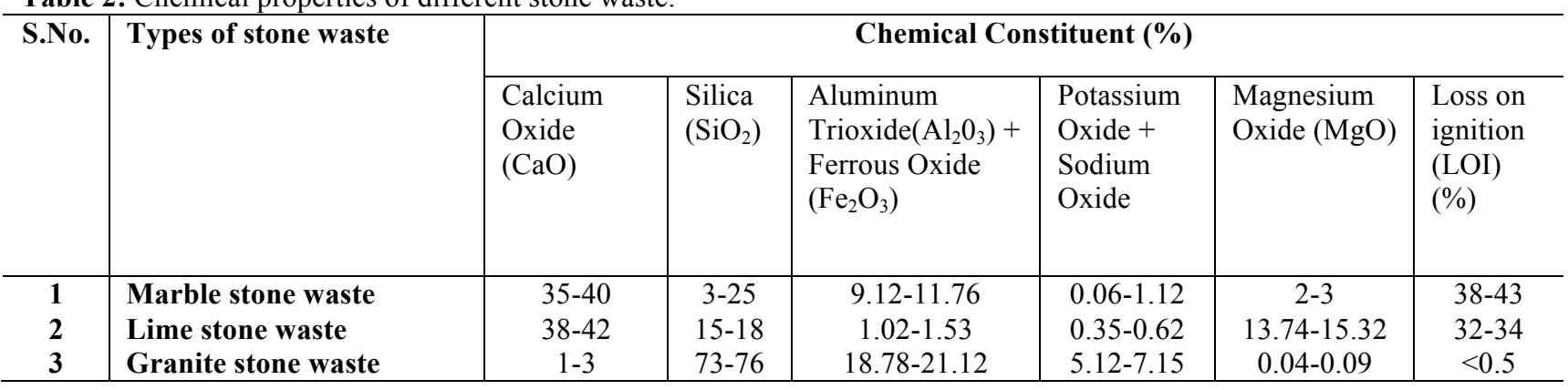

Table 3: Amount of substitution by Stone waste

\begin{tabular}{|c|c|c|c|}
\hline Reference & $\begin{array}{c}\text { Types of } \\
\text { composite/products }\end{array}$ & Types and amounts of substitution & Stone waste used \\
\hline Agarwal (2008) & Concrete & Cement; up to $30 \%$ & Lime stone slurry \\
\hline Agarwal (2008) & Mortar & Cement; up to $0-55 \%$ vol. & Lime stone polish slurry \\
\hline Agarwal (2008) & $\begin{array}{l}\text { High strength lime } \\
\text { binder }\end{array}$ & Cement; up to $100 \%$ & Lime stone quarry waste \\
\hline $\begin{array}{l}\text { Al-Akhras et. } \\
\text { al(2010) }\end{array}$ & Concrete & Sand; up to $5-15 \%$ by weight & $\begin{array}{l}\text { Marble burnt stone slurry (BSS) } \\
\text { waste }\end{array}$ \\
\hline $\begin{array}{l}\text { Alzboonet. } \\
\text { al(2009) }\end{array}$ & Concrete & Water; up to $25-100 \%$ & Marble stone cutting waste \\
\hline $\begin{array}{l}\text { Felekoglu et. } \\
\text { al(2007) }\end{array}$ & $\begin{array}{l}\text { Self-compacting } \\
\text { concrete }\end{array}$ & Cement; up to $10-40 \%$ & Quarry lime stone waste \\
\hline $\begin{array}{l}\text { Gnanavelet. } \\
\text { al(2009) }\end{array}$ & Bricks & Additive; up to $50 \mathrm{wt}$. $\%$ & $\begin{array}{l}\text { Granite and marble sawing powder } \\
\text { waste }\end{array}$ \\
\hline $\begin{array}{l}\text { Gsog luet. } \\
\text { al(2012) }\end{array}$ & $\begin{array}{l}\text { Self-compacting } \\
\text { concretes }\end{array}$ & Cement; up to $5-20 \%$ & Lime stone waste \\
\hline $\begin{array}{l}\text { Hamza et. } \\
\text { al(2011) }\end{array}$ & Concrete bricks & Aggregates; up to $40 \%$ & $\begin{array}{l}\text { Marble waste scrapes and slurry } \\
\text { powder }\end{array}$ \\
\hline $\begin{array}{l}\text { Omar Omar et. } \\
\text { al(2012) }\end{array}$ & Concrete & Sand; up to $25-75 \%$ & Lime stone quarry waste \\
\hline Patel et. al(2013) & Concrete & Cement; up to $10-50 \%$ & Marble stone powder waste \\
\hline $\begin{array}{l}\text { Rajgor et. } \\
\text { al(2013) }\end{array}$ & Fly ash bricks & Fly ash; up to $10-60 \%$ & Stone sludge \\
\hline $\begin{array}{l}\text { Topçu et. } \\
\text { al(2009) }\end{array}$ & $\begin{array}{l}\text { Self-compacting } \\
\text { concrete }\end{array}$ & Binder; up to $10-120 \%$ & Waste marble dust \\
\hline
\end{tabular}

\subsection{Fresh concrete properties Slump value}

The slump is used to measure the workability of fresh concrete mix. Being an important property, the slump of concrete and cement mortar mix containing stone waste was studied extensively.

In the majority of the studies, a lower slump value of fresh concrete due to the incorporation of several types of stone waste as compared to conventional concrete mix was observed and an increasing addition of stone waste further lowers the slump value. The reasons for the lower slump value of the concrete mix containing stone waste was the particle size of stone aggregate. In a few studies, an increase in the slump value due to the incorporation of stone waste was also reported, the increase of the slump of concrete mixes due to the incorporation of stone waste is due to the presence of more free water in the mixes containing stone waste than in the concrete mix containing natural aggregate. The possibility of using marble powder (MP) and limestone filler (LF) in the production of self-compacting concretes (SCCs) with and without fly ash was investigated [21]. The results obtained showed that as lime stone waste content increased, slump flow diameter and $T_{500} \mathrm{~mm}$ slump flow time was decreased.

Use of burnt stone slurry (BSS) waste by replacement with silica in concrete mixtures was investigated and found that in case of mortar, workability decreased with increment of BSS content due to the low rate of reaction of the BSS compared to that of cement [22].Also, the utility of quarry dust limestone powder (QLP) in self-compacting paste and concrete applications was investigated and it was concluded that the incorporation of QLP increased the viscosity of the cement paste at the same water/powder ratio and superplastizer dosage [23].

\section{Unit weight}

Irrespective of the type and size of substitutions, the incorporation of stone waste as aggregate generally decreases fresh and dry densities of the resulting concrete due to the fineness of stone waste aggregate [23-25].

The behavior of marble dust (MD) in self-compacting concrete (SCC), as filler material was studied [26]. The result obtained was that unit weight of SCC haddecreased because of increase in air content. In ceramics studies, the effect of incorporation of granite and marble sawing powder 
waste up to 50 wt. \% into the raw clay material used for brick manufacturing with the result that bulk density was increased as reject content increased at constant sintering temperature [27].

\section{Air content}

There is direct relationship between strength properties and air content. Each percent increase in air content can reduce compressive strength by $2 \%$ to $6 \%$ for moderate-strength concrete. Only few reports are available on the evaluation of air-content of cement mortar or concrete mixes containing untreated stone waste as aggregate. The behavior of marble dust (MD) in self-compacting concrete (SCC), as filler material was studied [26]. The result obtained showedthat air content of SCC had increased by using marble dust in SCC.

\section{Setting time}

In case of mortar, initial and final setting time decreased with increment of burnt stone slurry (BSS) content due to the low rate of reaction of the BSS compared to that of cement. The results showed that addition of marble dust accelerate the setting. The results of initial and final setting times of control (OPC) and OPC blended with marble dust $(20 \%, 40 \%$ and $60 \%)$ and rice husk ash $(10 \%, 20 \%$ and $30 \%$ ) are shown in Fig. 4 :

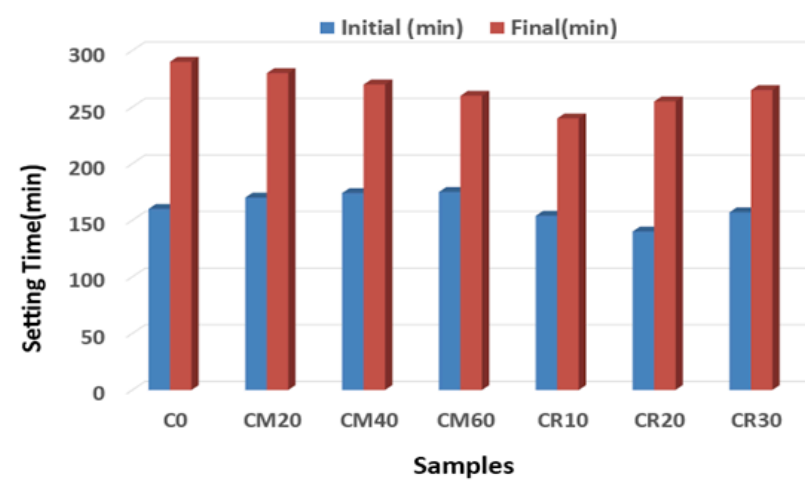

Fig. 4. Effect of mineral admixtures on the setting time of OPC.

The possibility of using marble powder (MP) and limestone filler (LF) in the production of self-compacting concretes (SCC) with and without fly ash was investigated [21]. To observe the replacement levels of MP and LF, seven binary and six ternary blends of SCC mixtures apart from a control mixture were designed. The results were obtained showed that as stone waste content increased, initial and final setting times increased than that of controlled specimen by replacing cement.

\subsection{Hardened concrete properties Compressive strength}

The compressive strength of concrete and cement mortar is a fundamental property that is thoroughly studied in almost all research works. Literature studies showed that the incorporation of stone waste such as limestone, marble and marble with granite stone waste etc. as an aggregate decreased the compressive strength of the resulting concrete/mortar with the replacement of cement due to less binding effect and increased with sand replacement due to filler effect [23, 24, 28-32].
The behavior of marble dust (MD) in self-compacting concrete (SCC), as filler material had been studied [26]. For this purpose,MD had replaced binder of SCC at certain contents of $0, \quad 50,100,150,200,250$ and 300 $\mathrm{kg} / \mathrm{m}^{3}$. Compressive strength was determined at the end of 28 days for the hardened concrete specimens. It was found thatthe compressive properties of hardened SCC had decreased by using MD as shown in Fig. 5.

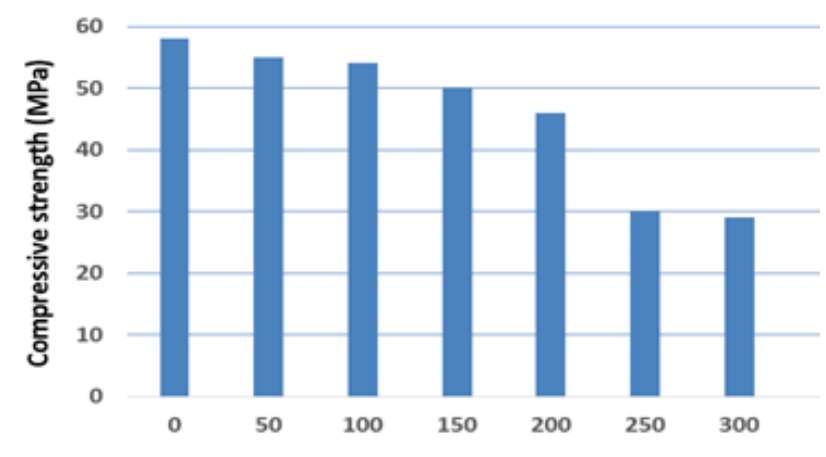

Replacement with cement $\left(\mathrm{kg} / \mathrm{m}^{3}\right)$

Fig. 5. Compressive strength of 28 agedSCC with cement replacement

Experimental study to investigate the strength variation in concrete and mortar by replacement of sand with stone waste had been carried out as shown in Fig. 6 [33]. Compressive strength of mortar was found to $33.02 \mathrm{MPa}$ at proportions of 1:2.75 which was $21 \%$ higher than conventional. The compressive strength of concrete was also observed $31 \mathrm{MPa}$ at proportions of $1: 1.5: 3$ which was $14.76 \%$ higher than that of normal sand (26 MPa).

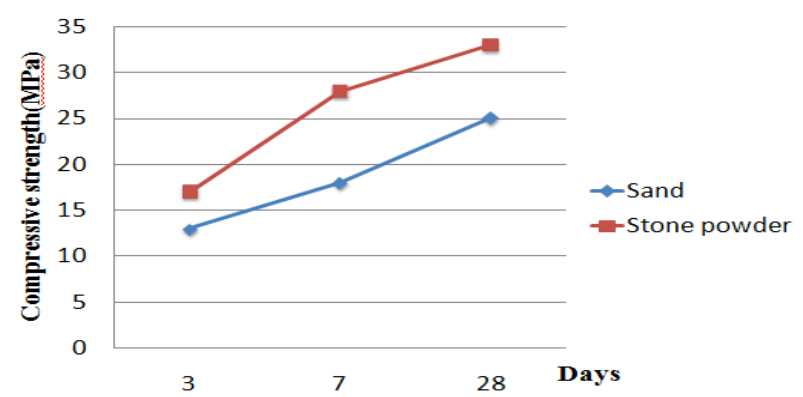

Fig. 6. Compressive strength v/s duration for mortar of 1:2.75 with sand replacement.

\section{Splitting tensile strength}

As shown in case of compressive strength, the incorporation of any type of stone waste decreased the tensile strength of the resulting concrete/mortar with the replacement of cement and increased with sand replacement. The tensile strength behavior of mortar containing various percentages of limestone waste (LSW) and marble powder (MP) are presented in Table 4[34].

Table 4. Test results for Splitting tensile strength.

\begin{tabular}{|c|c|c|}
\hline$\%(L S W)$ & $\%$ (MP) & $\begin{array}{c}f_{\text {sp }}, 28 \text { days }(\mathrm{MPa}) \\
\text { At cement content } 350 \\
\mathrm{Kg} / \mathrm{m}^{3} \\
\end{array}$ \\
\hline 0 & 0 & 3.7 \\
\hline 0 & 15 & 4.1 \\
\hline 50 & 15 & 4.5 \\
\hline
\end{tabular}


The experimental study undertaken to investigate the influence of partial replacement of sand with limestone waste (LSW), with marble powder (MP) as an additive on the concrete properties was reported [35]. The replacement proportion of sand with limestone waste, $25 \%, 50 \%$, and $75 \%$ were practiced in the concrete mixes .Besides, proportions of $5 \%, 10 \%$ and $15 \%$ marble powder were practiced in the concrete mixes. The result showed that tensile strength increases with the increment of lime stone waste.

\section{Modulus of elasticity (E)}

According to ASTM C 469, the modulus of elasticity is defined as a stress to strain ratio value for hardened concrete. The type of aggregate influences this modulus, since the deformation produced in concrete is partially related to the elastic deformation of the aggregate. The effect of stone waste on the behavior of concrete's modulus of elasticity is reported in some research paper.

The use of marble and granite (MGR) as a sustainable alternative for cement replacement was investigated [30]. Chemical analysis and particle size distribution showed that MGR was a non-reactive material and may act as filler. In this work, experimental research had been conducted where $5 \%, 10 \%$ and $20 \%$ of the cement was replaced by MGR. Elastic modules test was conducted to examine the mechanical performance of concrete containing MGR and results showed that $\mathrm{E}$ decreased as \% mixed waste increased at constant $(\mathrm{w} / \mathrm{c})$ ratio and also $\mathrm{E}$ decreased as $\mathrm{w} / \mathrm{c}$ ratio increased at constant $\%$ mixed waste. Mohamadien et al. reported the experimental study undertaken to investigate the influence of partial replacement of sand with limestone waste (LSW) and marble powder (MP) as an additive on the concrete properties. The replacement proportion of sand with limestone waste $25 \%, 50 \%$, and $75 \%$ were practiced in the concrete mixes. Besides, proportions of $5 \%, 10 \%$ and $15 \%$ marble powder were practiced in the concrete mixes. The result showed that the modulus of elasticity increased with increasing the limestone waste with marble powder.

\section{Flexural strength}

Flexural strength is defined as the material's ability to resist deformation under flexural load and is measured in terms of stress. It represents the highest stress experienced within the material at the collapse load.

Use of burnt stone slurry (BSS) waste by replacement with silica in concrete mixtures was investigated [22]. To make samples portland cement (Type I), natural silica sand, BSS and water were used. BSS was added to mortar mixtures as a partial replacement of the silica sand at three levels $5 \%, 10 \%$, and $15 \%$ by weight. Curing of samples was done by both moist curing and autoclaving curing. It was noticed that up to $10 \%$ replacement the flexural strength increased. However strength by autoclave curing was more than moist curing due to the high temperature of autoclaving curing that leads to higher speed of hydration and consequently leads to higher concrete strength. This behavior of strength was due to high amount of lime in BSS which reacts with silica forming additional C-S-H gel which contributes to the increase in the strength. The behavior of marble dust (MD) in self-compacting concrete (SCC), as filler material was studied [26]. The result showed that flexural properties of hardened SCC had decreased by using Marble dust waste.

The utilization of waste marble dust as an additive material in industrial brick was investigated [35]. In general, the addition of waste up to levels of $10 \mathrm{wt} . \%$ did not play significant changes in the relevant functional characteristics, but when the amount of marble powder additives were increased, the physico-mechanical properties of bricks were increased remarkably. The results for this study showed that $10 \%$ by weight of marble powder can be added to an industrial brick mortar with no sacrifice of technical properties of the final product. Adding waste marble more than $10 \mathrm{wt}$ \% decreased flexural strength drastically.

Characterization laboratory tests on samples that were molded with different marble powder contents was carried out, fired at temperature varying from 750 to $950{ }^{\circ} \mathrm{C}$. The results depicted the possibility of using this by-product in the paste composition of ceramic bricks [36]. It was found that at different temperature and different waste content the strength varies as shown in Fig.7.

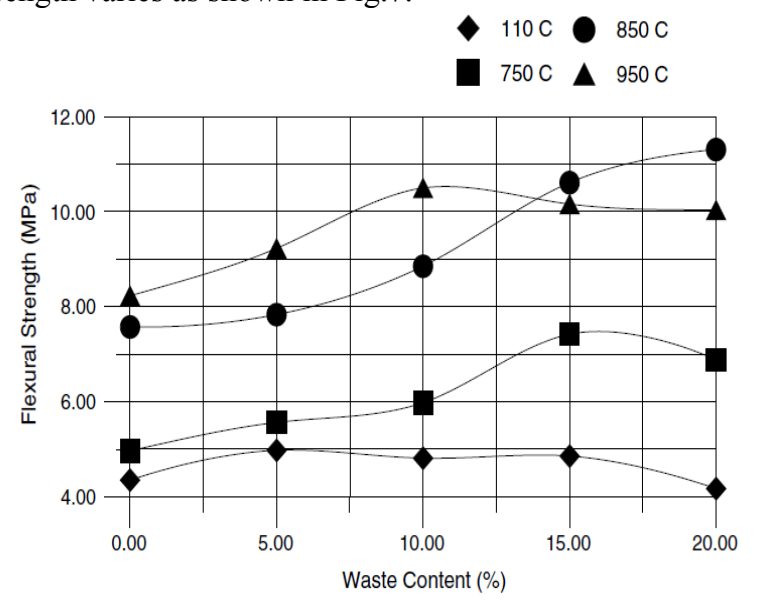

Fig. 7. Flexural strength with waste content.

\subsection{Durability performance}

Various durability factors evaluated for concrete or mortar containing stone waste consist ofwater absorption, sorptivity, shrinkage, carbonation resistance, chloride ion permeation and resistance against freezing and thawing which are described below:

\section{Permeability behaviour}

Generally the permeability of aggressive chemical species through the pores of concrete is the major factor that controls several durability properties. Tests like water absorption, gas permeability and chloride permeability measurement can provide information on the vulnerability of concrete to the ingress of deleterious chemical species.

\section{Capillarity property}

The behavior of marble dust (MD) in self-compacting concrete (SCC), as filler material was studied [26]. For this purpose, MD had replaced binder of SCC at certain contents of $0,50,100,150,200,250$ and $300 \mathrm{~kg} / \mathrm{m}^{3}$ and the result obtained are given in Fig.8. The capillarity property of hardened SCC had increased by using Marble dust waste in large amount i.e. above $150 \mathrm{~kg} / \mathrm{m}^{3}$. The utilization of marble waste of different sizes in the manufacturing of concrete bricks, with full replacement of conventional coarse and fine 
aggregates with marble waste scrapes and slurry powder of content up to $40 \%$ was studied [37]. The test result about water absorption is shown in Fig.9 that qualifies them for use in the building sector.

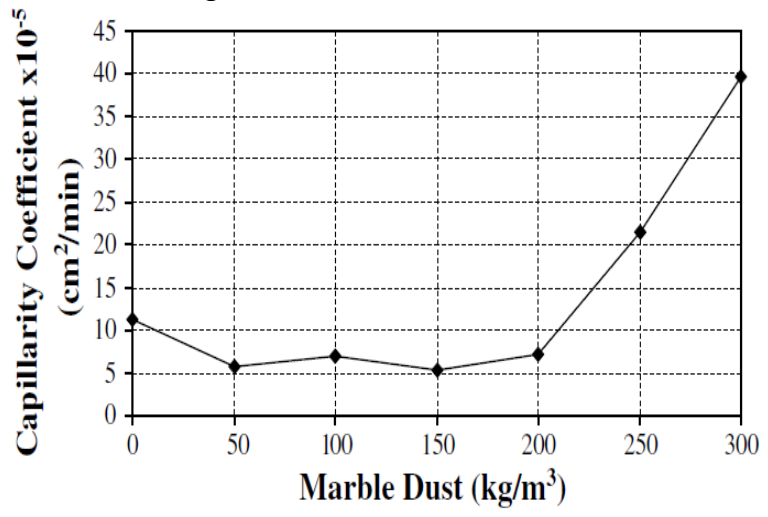

Fig. 8. Variation of capillary coefficient

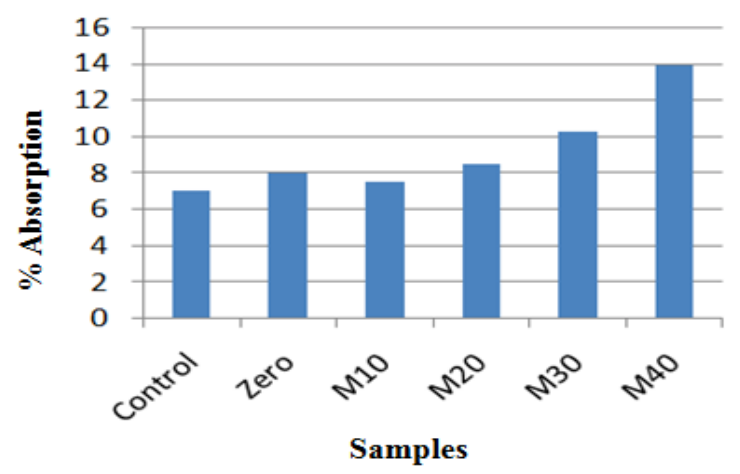

Fig. 9. Water absorption for marble slurry related to filler content.

The use of waste marble dust as an additive material in industrial brick was studied [35]. Waste material in different proportions was mixed with industrial brick mortar starting amount from 0 to $80 \mathrm{wt}$ \%. Archimedes water displacement test was conducted with different water absorption percentage values at 900,1000 and $1100^{\circ} \mathrm{C}$ temperatures. From Fig.10 it can be seen that the porosity values of waste mixed bricks increased with the increasing waste. One of the reasons of this result is the $\mathrm{CaO}$ mineral in the waste marble.

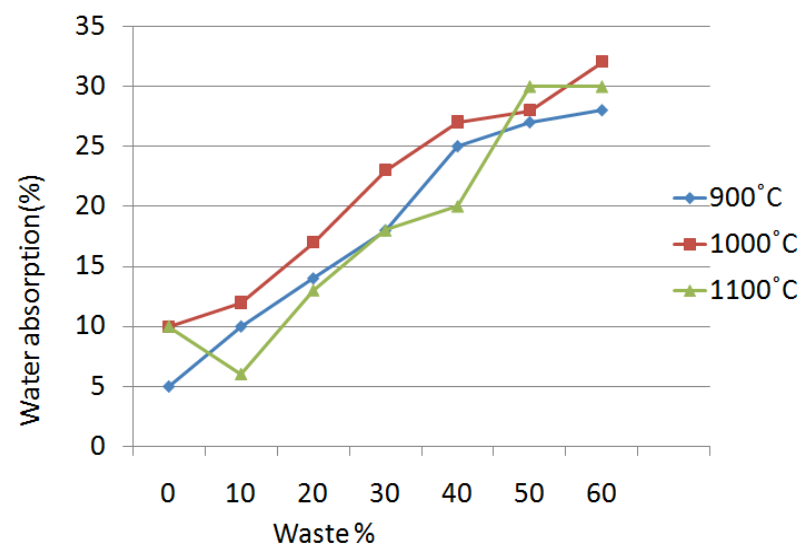

Fig. 10. Water absorption with increasing amount of waste additives in brick compositions.

\section{Porosity}

Voids in concrete can be filled with air or water.Air voids are obvious and easily-visible example of pores in concrete. Broadly speaking, the more porous the concrete, the weaker it will be. Probably the most important source of porosity in concrete is the ratio of water to cement in the mix. The use of powdered marble by-product to enhance the properties of brick ceramic, fired at temperature varying from 750 to $950^{\circ}$ $\mathrm{C}$ and mechanical properties were evaluated [36]. The result obtained showed that at $15 \%$ replacement of stone waste the open porosity was less, as shown inFig. 11 .

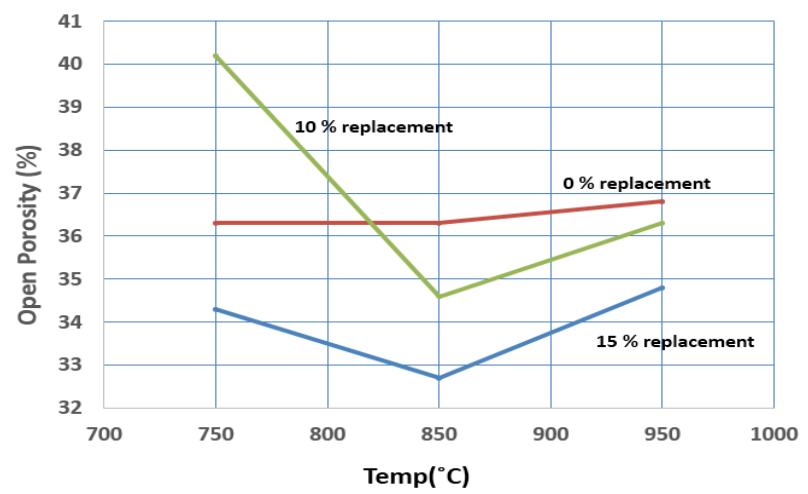

Fig. 11. Variation of open porosity with temperature and waste content.

Use of burnt stone slurry (BSS) waste by replacement with silica in concrete mixtures was investigated [22]. To make samples portl and cement (Type I), natural silica sand, BSS and water were used.BSS was added to mortar mixtures as a partial replacement of the silica sand at three levels i.e. $5 \%, 10 \%$ and $15 \%$ by weight. Curing of samples was done by both moist curing and autoclave curing. The moist cured mortar had higher degree of porosity in comparison with the autoclaved mortar. This behavior was due to the effect of autoclaving curing that produced more packing structure of mortar specimens compared to the moist curing. In this area, The usability of waste marble dust as an additive material in industrial brick was investigated [35]. Waste material in different proportions was mixed with industrial brick mortar starting amount from 0 to $80 \mathrm{wt}$ \%. Sintering at three different temperatures 900,1000 and $1100^{\circ} \mathrm{C}$ was done and the result showed that there is increase in porosity with the increasing amount of marble powder.

Chloride ion permeability and electrical resistivity

The possibility of using marble powder (M) and limestone filler (LF) in the production of self compacting concrete (SCC) with and without fly ash was investigated [21]. Rapid chloride permeability, electrical resistivity and sorptivity properties of SCC were determined at 90 days of curing. The results obtained showed that with the increase of lime stone waste, chloride ion permeability decreases whereas electrical resistivity increases.

\section{Shrinkage}

The use of the powder marble by-product to enhance the properties of brick ceramic was studied [36]. It has been observed that the specimens fired at $850^{\circ} \mathrm{C}$ and $950{ }^{\circ} \mathrm{C}$ have shown similar behavior, where a very small decrease of linear variation between $0 \%$ and $5 \%$ of waste content was 
noticeable. The result obtained showed that at lower temperature of sintering the linear shrinkage was less as compared to other higher temperatures as shown inFig. 12:

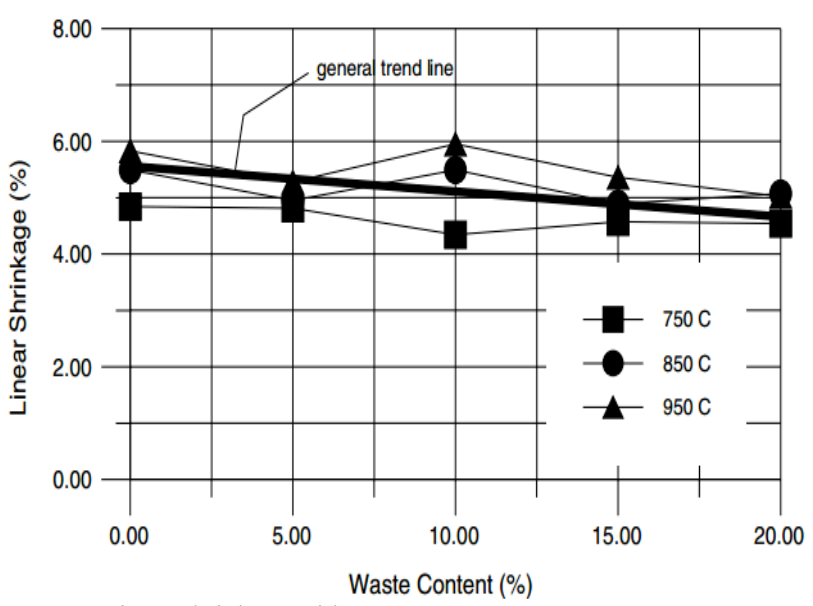

Fig. 12. Linear shrinkage with waste content.

Use of burnt stone slurry (BSS) waste by replacement with silica in concrete mixtures at three levels $5 \%, 10 \%$, and $15 \%$ by weight was investigated [22].The results obtained are shown as follows in Fig.13.

- Expansion in case of moist curing was more than that of autoclave curing

- In case of moist curing as \% BSS increased, expansion was also increased

- In case of autoclave curing expansion at $10 \%$ replacement was same as that of $0 \%$ replacement

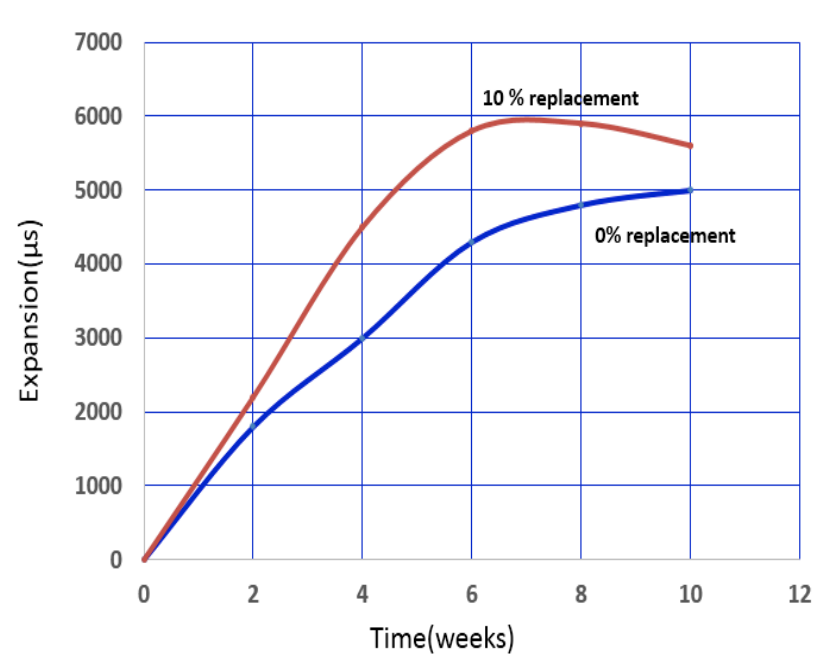

Fig. 13. Effect of BSS replacement on the durability.

The changes in the physical and mechanical properties of the produced ceramic tiles from raw materials containing marble sludge slime produced in the ornamental stone processing industry was investigated [38]. The replacement of all the bentonite by sludge slime significantly decreased the shrinkage values of the tiles from $1.66 \%$ to $0.5 \%$. The results showed that all of the produced sludge slime can be consumed successfully in ceramic production.

\section{Practical implications}

The above discussion proves that the incorporation of stone waste as replacement of sand in cement composites can improve various properties such asstrength (compressive/tensile/flexural), thermal resistance, abrasion resistance, shrinkage, cracking increases which can solve a part of the problem associated with stone waste disposal.The practical implications of the results till date are given below in Fig. 14.

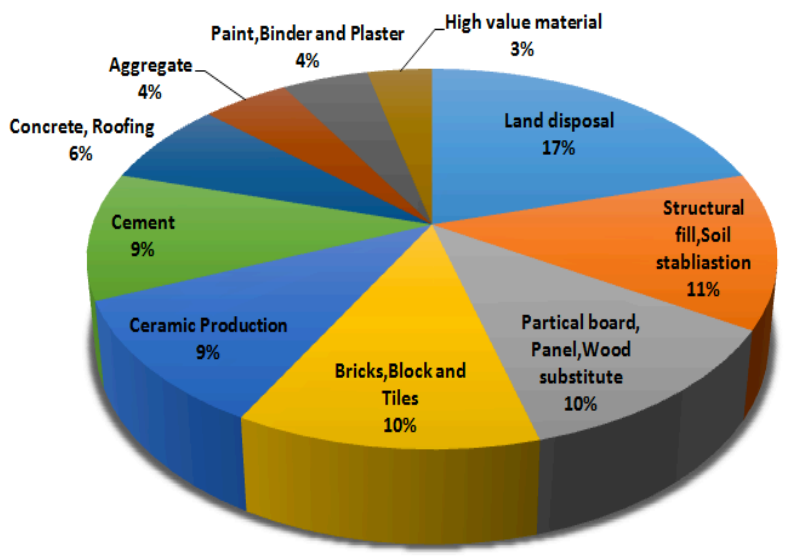

Fig. 14. Stone waste utilization.

\section{Conclusions}

From the literature studies, it can be inferred that stone waste can be utilized for developing low cost building materials such as block, brick, tiles etc., however following studies are also recommended for utilizing this waste as an effective replacement of sand:

- Stone cutting powder with fly ash/rice husk ash/ ground granulated blast-furnace slag (GGBS) in cement concrete as mineral admixtures for the development of low cost building materials

- Development of lightweight block/panel for thermal and acoustic insulation purpose

- Study of lime stone waste as sustainable fillers in polymer matrices

- Microstructural study of different inorganic matrix with stone waste

\section{Acknowledgments}

Authors are thankful to Prof. S.K. Bhattacharya, Director, CSIR-Central Building Research Institute, Roorkee, India for granting the permission of publishing this paper. 


\section{References}

1. Acchar, W., Vieira, F.A. and Hotza, D. (2006) Effect of marble and granite sludge in clay materials. Materials Science and Engineering419: pp. 306-309.

2. Almeida, N., Branco, F., Santos, J.R. (2007) Recycling of stone slurry in industrial activities: application to concrete mixtures. Build Environ: pp.810-9.

3. Farhana1, S., Parmar ,B., , Prajapati ,J., Pitroda, J.K. (2013) A Study on Utilization Aspects of StoneChipsas an Aggregate Replacement in Concrete in Indian Context. International Journal of Engineering Trends and Technology (IJETT) - Volume 4(8).

4. Monteiro, P.J.M., Mehta, P.K. (2006) Concrete microstructure, properties, and materials. $3^{\text {rd }}$ ed. McGraw Hill Company.

5. Patel, A.N.C. and Pitroda, J.K. (2013) Stone waste: Effective replacement of cement for establishing green concrete. International journal of innovative technology \& exploring engineering: Vol.2(5).

6. Nanda, R. P., Das, A. K. and Moharana,N.C(2010) Stone crusher dust as a fine aggregate in Concrete for paving blocks. International journal of civil and structural engineering; Volume 1(3).

7. Safiuddin, Mohd.,Jumaat, Mohd. Z., Salam,M. A., Islam,M. S. and Hashim ,R. (2010). Utilization ofsolid waste in construction materials. International Journal of the Physical Sciences Vol. 5(13): pp.1952-1963.

8. Awol,A.(2011) Using Marble waste powder in cement and concrete production . A M.Sc. Thesis to the School of Graduate Studies of Addis Ababa University.

9. Binici, H., Kaplan, H. and Yilmaz, S. (2007) Influence of marble and limestone dusts as additives on some mechanical properties of concrete. Sci Res Essay; pp.372-379.

10. Demirel, B. (2010) The effect of the using waste marble dust as fine sand on the mechanical propertiesof the concrete. International Journal of the Physical Sciences; Vol. 5(9): pp. 1372-1380.

11. Hebhoub H, Aoun M, Belachia, Houari H, Ghorbel E(2011) Use of waste marble aggregates in concrete. Constr Build Mater; Volume 25:pp.1167-71.

12. Kumar, A., Khan, N. H, Rai, B., Duggal, S.K.(2011) Influence of Marble powder/granules in Concrete mix. International journal of civil and structural engineering; Volume 1(4).

13. Moreira, J. M. S., Freire,M. N. and Holanda, J. N. F. (2005) Utilization of Granite Powder Waste in Ceramic Bodies for Civil Construction. Universidade Estadual do Norte Fluminense.

14. Shirule, P.A., Rahman, A., Gupta, R. D. (2012) Partial replacement of cement with marble dust powder. International Journal of Advanced Engineering Research and Studies, IJAERS; Volume 1(3): pp. 175- 177.

15. Tekeli, S., Akın, E.(2007) Manufacturing of polymer matrix composite material using natural stone dust and fly ash. Key Eng Material :pp. 336-338.

16. Terzi, S.(2007)Evaluation of natural stone waste dust in the mixture of asphaltic concrete. Constr Build Mater ;21:pp. 616-20.

17. Torres, P., Fernandes,H.R., Agathopoulos, S., Tulyaganov, D.U. and Ferreira, J.M.F. (2004) Incorporation of granite utting sludge in industrial porcelain tile formulations. Journal of the EuropeanCeramic Society 24: pp. 3177-3185.

18. Veera Reddy,M.(2010) Investigations on stone dust \& ceramic scrap as aggregate replacement in concrete. International journal of civil and structural engineering, Volume 1, No 3.

19. Vijayalakshmi, M., Sekar, A.S.S., Ganesh prabhu, G.(2013)Strength and durability properties of concrete made with granite industry waste. Construction and Building Materials 46: pp.1-7.

20. Yazıcioglu, S., Arslan, EI., Aslan, S., Ipek, U., Altun, S.(2005) Physico-chemical treatment of natural stone processing wastewater and the recycling of its sludge. Waste Manage Res ;23: pp. 550-9.

21. Gsog־lu, M., Güneyisi, E., Kocabag, M. E., Bayram, V.and Mermerdas, K. (2012) Fresh and hardened characteristics of Self compacting concrete made with combined use of marble powder, limestone filler, and fly ash. Construction and Building Materials 37: pp.160-170.
22. Al-Akhras, N. M., Ababneh, A.And Alaraji, W. A. (2010) using burnt stone slurry in mortar mixes. Construction and Building Materials 24: pp. 2658-2663.

23. Felekoglu, B. (2007) Utilisation of high volumes of limestone quarry waste in concrete industry (self- compacting concrete case. Resources, Conservation and Recycling 51: pp. 770-791.

24. Algin, H.M. and Turgut, P. (2008) Cotton and limestone powder waste as brick material. Construction and Building Materials 22: pp.1074-1080.

25. Pappu ,A., Saxena, M. and Asolekar ,S.R. (2007) Solid waste generation in India and their recycling potential in building materials. Building and Environment. 42: pp.2311-2320.

26. Topçu, I. B., Bilir, T. and Uygunog lu, T.(2009) Effect of waste marble dust content as filler on properties of self-compacting concrete. Construction and Building Materials 23: pp.1947-1953.

27. Gnanavel, B., Dhanapandian, S. (2009) An investigation on the effect of incorporation of granite and marble waste in the production of bricks. ARPN Journal of Engineering and Applied Sciences: VOL. 4(9), ISSN 1819-6608.

28. Awol,A.(2011) Using Marble waste powder in cement and concrete production . A M.Sc. Thesis to the School of Graduate Studies of Addis Ababa University.

29. Bacarji, E., Filho, Toledo R.D., Koenders,E.A.B., Figueiredo ,E.P.and Lopes, J.L.M.P. (2013) Sustainability perspective of marble and granite residues as concrete fillers. Construction and Building Materials 45: pp. 1-10.

30. Ballester, P., Mármol, I., Morales, J. and Sánchez, L. (2007) Use of limestone obtained from waste of the mussel cannery industry for the production of mortars. Cement and Concrete Research 37: pp. 559-564.

31. Bilgin, N., Yeprem, H.A., Arslan, S., Bilgin, A., Günay, E. and Marsoglu, M. (2011) Use of waste marble powder in brick industry. Construction and Building Materials 29: pp.449-457.

32. Bobadilla-Sánchez, E. A., Martínez-Barrera, G., Brostow, W.and Datashvili, T. (2009) Effects of polyesterfibers and gamma irradiation on mechanical properties of polymer concrete containing $\mathrm{CaCO}_{3}$ and silica sand. eXPRESS Polymer Letters; Vol.3(10) :pp.615-620.

33. Mahzuz, H.M.A.Yusuf, M.A. and Ahmed, A. A. M. (2011) Use of stone powder in concrete and mortar asan alternate of sand. African Journal of environment science and technology; Vol.5 (5):pp.381388.

34. Omar Omar, M., Abd Elhameed, G. D., Elhameed, A., Sherif ,M A. and Mohamadien, H.A.(2012) Influence of limestone waste as partial replacement material for sand and marble powder in concreteproperties. HBRC Journal 8 : pp.193-203.

35. Bilgin, N., Yeprem, H.A., Arslan, S., Bilgin, A., Günay, E. and Marsoglu, M. (2011) Use of waste marble powder in brick industry. Construction and Building Materials 29: pp.449-457.

36. Xavier, G.C., Alexandre, J. and Saboya, J. F. (2007) The use of the powder marble by-product toenhance the properties of brick ceramic. Construction and Building Materials 21: pp.1950-1960.

37. Hamza, R. A., El-Haggar, and Khedr ,S.(2011) Marble and Granite Waste: Characterization and Utilization in Concrete Bricks. International Journal of Bioscience, Biochemistry and Bioinformatics:Vol. 1(4).

38. Al-Hamaiedh, H. (2010) Reuse of Marble Sludge Slime in Ceramic Industry. Jordan Journal of Civil Engineering; Volume 4(3). 